\title{
Teaching Teachers for Brazilian Universities: A Content Analysis of Scientific Publications Focused on the Sustainability of Stricto Sensu Programs
}

\author{
Lilian Gavioli $^{1}$, \& Paulo Reis Mourão ${ }^{2}$ \\ ${ }^{1}$ School of Social Science, University of Minho, Braga, Portugal \\ ${ }^{2}$ School of Economics and Management/NIPE, University of Minho, Braga, Portugal \\ Correspondence: Paulo Reis Mourão, School of Economics, University of Minho, Campus of Gualtar, 4700, Box: \\ 33, Braga, Portugal. E-mail: paulom@eeg.uminho.pt
}

Received: September 29, 2019

Accepted: October 26, 2019 Online Published: November 1, 2019

doi:10.5539/hes.v9n4p167

URL: https://doi.org/10.5539/hes.v9n4p167

\begin{abstract}
After more than four decades of post-graduate programs in Brazil focused on the preparation of teachers - the Stricto and Lato Sensu programs - we have verified a gearing frequency of academic works that reflect on these programs. Through a bibliometric analysis and a content analysis of scientific publications focused on the Stricto Sensu programs we conclude that the current stage of research development shows that these programs are associated with a concentrated focus on research and that pedagogical preparation is being made secondary. The methodology used was qualitative, data from the Brazilian Platform for Higher Education Personnel Improvement Coordination (CAPES) and the Scientific Electronic Library Online (Scielo) were used and analyzed using the Iramuteq software.The results showed that since the 2000s the number of doctoral theses and master's dissertations has grown and the area with the most publications refers to the health sciences.This bias motivates an accessory debate as well as revealing the implications of the focus of these programs.
\end{abstract}

Keywords: Brazilian education, teacher education, teaching in higher education, Stricto Sensu, Vosviewer

\section{Introduction}

Since the publication of Law No. 977/1965, the education of teachers being prepared to work at the higher education level has been emphasized in Brazil. That document considered as a priority the training of professors and researchers to meet teaching needs. This priority was a result of the scientific and technological development in the country during the 1960s. A review of the literature indicates that it is perceived that teacher education in Brazil has been developed focused on research and teaching. In this sense, it is necessary to (re) think the need for teacher training that also takes teaching practice into consideration as professors of higher education are expected to be involved in academic teaching. Several published studies have analyzed teaching in higher education as a field in which there is still much to be done. At the moment, some of preparation is based on "a discipline of Methodology of Higher Education, in the moments of the post-graduate, with average hourly load of 60 hours" (Anastasiou, 2002). There are several authorities and orientations based on which the academic teacher can act in the classroom. Analyzing the syllabuses of the discipline in several higher education courses aimed at teacher education reveals that, as a general rule, there is little content related to basic knowledge for the teaching profession or to the process that allows the construction of the professional identity of the teacher (Anastasiou \& Pimenta, 2002). This lack of teacher training in relation to exercise in higher education is justified by the fact that for some researchers, teacher education is a moment of activity characterized as unsystematic, with little rigor and little research, [since] it did not exist until today a tradition of professional training in higher education, and young teachers have always been left alone, except perhaps for a short course of initiation (Garcia, 1999).

Thus, this article reflects on the reading allowed by an exhaustive analysis of a vast list of published literature on graduate programs in Brazil. We have tested the hypothesis that these programs are being perceived as more focused on preparation for the scientific production of the trainees, i.e., the dimension of the investigation evidenced by metrics on the publications of the graduates or coauthored by the graduates. Therefore, there has been an inattention (or a secondary attention) to pedagogy and the civil extension of the academy. Section 2 of 
the article presents the Brazilian higher education: the Stricto-Sensu modality and have 5 subdivisions: Synthesis of Literature Review and the Methodology, on the Beginning of the Post-Graduate course in Brazil, The Issue of Standardization/Heterogeneity of Curricula, Emerging Challenges and Empirical section - a content analysis of the consulted publications.

Section 3 presents the results and finally, the section 4 presents the discussion, the conclusion and recommendations.

\section{Brazilian Higher Education: the Stricto-Sensu Modality}

\subsection{Synthesis of Literature Review and the Methodology}

The methodology used is qualitative, data were collected from the following platforms: Higher Education Personnel Improvement Coordination (CAPES) and the Scientific Electronic Library Online (Scielo) were used and analyzed using the Iramuteq software.

The preparation of future teachers in higher education in Brazil is the primary objective of the Stricto Sensu programs addressed here. It is expected that a teacher in higher education in Brazil - as in most other countries will be a trainer/teacher of generations of students studying certain branches of science but will also continuously produce new scientific knowledge and take an active or collaborative position with the so-called civic/outreach extension of the academy (such as participation in projects to disseminate knowledge, volunteer training, and participation in public debates). Although academic work is a continuous curricular development activity - evaluated periodically by the institutions and reported from time to time - the preparation of the teacher in higher education has deserved greater reflection in the last decades.

From the previous readings, it was established that the various authors distributed the focus of their publications into three main dimensions: the recognition of Stricto Sensu as an opportunity to launch a renewed research base in Brazil, the vision of the programs as an opportunity for the development of the pedagogical capacities of the future teachers of higher education, and the possibility of extension of the programs as motors of socio-economic development in the regions. However, there is a more dominant tone in the various papers that we will consider as our main hypothesis: the tendency of the Stricto Sensu programs to be centered on the research dimension. It is clear that the authors cited do not converge on their evaluations of the Stricto Sensu programs. Thus, in order to test our main hypothesis - the focus of the Stricto Sensu programs on research - we will run, in the next section, a content analysis of the published material referring to the Stricto Sensu programs.

\subsection{On the Beginning of the Post-graduate Course in Brazil}

In the mid-1950s, Stricto Sensu post-graduate programs began in Brazil, motivated by the national post-graduate policy (2006). In this period, Brazil underwent economic transformations in which the majority of the population made a rural exodus and migrated to urban centers in search of new means of survival. The insertion of the "rural" people into urban environments generated in Brazil a process of urbanization. The example of the São Paulo ABCD (a region composed of the municipalities of Santo André, São Bernardo, São Caetano do Sul, and Diadema) is frequently cited, where the need for economic development in the region was essentially technical and non-academic (Rolnik, 1994). The economic development of Brazil was seen by many authors (Barilli, 1998; Guterres, 2001) as the major driver of the growing demand for university courses. As Rolnik (1994) discovered in the case of ABCD in São Paulo, the urbanization process, urban migration, and marked industrialization motivated a sharp increase in the demand for technical training. In fact, in the period between 1994 and 2001 there was a growth in the number of students enrolled in post-graduate schools: $31 \%$ in master's degree programs and $73 \%$ in doctoral programs. These results mainly refer to enrollments in federal and state institutions (Porto \& Régnier, 2018). Restrictions on the Stricto Sensu modality in Brazil started to be lifted due to the implantation of new curricular guidelines and the reduction of the time to the conclusion of the program after the 1990s. Employability in public examinations or in selective processes in private institutions motivated students to enter and to finish their studies.

Table 1 is exhibited in order to begin this discussion with an analysis of the associated chronology. 
Table 1. Brazilian institutes of research and their dates of creation.

\begin{tabular}{|c|c|c|}
\hline $\mathbf{N}^{\mathbf{0}}$ & Research Institutes & $\begin{array}{l}\text { YEAR of } \\
\text { creation }\end{array}$ \\
\hline 01 & Botanical Garden of Rio de Janeiro & 1808 \\
\hline 02 & National Museum & 1818 \\
\hline 03 & National Observatory & 1827 \\
\hline 04 & $\begin{array}{l}\text { Sociedade Preparadora de Educação Popular (transformed into the Lyceum of Arts and } \\
\text { Crafts of São Paulo in 1882) }\end{array}$ & 1873 \\
\hline 05 & School of Mining and Metallurgy at Ouro Preto & 1876 \\
\hline 06 & Agronomic Institute of Campinas & 1887 \\
\hline 07 & Bacteriological Institute of the State of São Paulo (currently Instituto Adolfo Lutz) & 1893 \\
\hline 08 & Polytechnic School & 1893 \\
\hline 09 & Instituto Manguinhos (currently Oswaldo Cruz Foundation and Fiocruz) & 1900 \\
\hline 10 & Instituto Serumtherapico (currently Instituto Butantã) & 1901 \\
\hline 11 & Pasteur Institute & 1903 \\
\hline 12 & Ezequiel Dias Institute & 1907 \\
\hline 13 & $\begin{array}{l}\text { Geological and Mineralogical Service of Brazil (currently Geological and } \\
\text { Mineralogical Institute of Brazil) }\end{array}$ & 1907 \\
\hline 14 & São Paulo Medical School & 1912 \\
\hline 15 & Experimental Station of Fuels and Ores (currently National Institute of Technology) & 1921 \\
\hline 16 & Institute for Development and Rational Organization of Labor - IDORT & 1931 \\
\hline 17 & $\begin{array}{l}\text { National Institute of Statistics - INE (currently Brazilian Institute of Geography and } \\
\text { Statistics - IBGE) }\end{array}$ & 1934 \\
\hline 18 & National Department of Mineral Research (or Mineral Production) - DNPM & 1934 \\
\hline 19 & Institute of Technological Research - IPT & 1934 \\
\hline 20 & $\begin{array}{l}\text { National Institute of Pedagogy (currently National Institute of Educational Studies and } \\
\text { Research Anísio Teixeira - INEP) }\end{array}$ & 1937 \\
\hline 21 & $\begin{array}{l}\text { Institute of Electrotechnology of USP (currently Institute of Electrotechnics and Energy } \\
\text { IEE-USP) }\end{array}$ & 1940 \\
\hline 22 & Military Institute of Technology (currently Military Engineering Institute - IME) & 1941 \\
\hline \multirow{2}{*}{23} & Getúlio Vargas Foundation & 1944 \\
\hline & University Statute & 1945 \\
\hline 24 & Technical Institute of Aeronautics - ITA & 1947 \\
\hline 25 & Brazilian Society for the Advancement of Science - SBPC & 1948 \\
\hline 26 & Brazilian Center for Physical Research - CBPF & 1949 \\
\hline 27 & National Council of Scientific and Technological Development - CNPq & 1951 \\
\hline 28 & $\begin{array}{l}\text { Campaign for the Improvement of Higher Education Personnel (currently Coordination } \\
\text { Foundation for the Improvement of Higher Education Personnel - CAPES) }\end{array}$ & 1951 \\
\hline 29 & National School of Sciences of the IBGE & 1952 \\
\hline 30 & National Institute of Research of the Amazon - INPA & 1952 \\
\hline \multirow[t]{2}{*}{31} & Institute of Pure and Applied Mathematics & 1952 \\
\hline & Institute of Radioactive Research (UFMG) & 1952 \\
\hline 32 & Brazilian Institute of Bibliography and Documentation - IBBD & 1954 \\
\hline 33 & $\begin{array}{l}\text { Institute of Atomic Energy of São Paulo - USP - IEA (Transformed into the Institute of } \\
\text { Energy and Nuclear Research IPEN) }\end{array}$ & 1956 \\
\hline 34 & Institute of Road Research & 1957 \\
\hline \multirow[t]{2}{*}{35} & Institute of Nuclear Energy - IEN & 1962 \\
\hline & Post-graduate Institutions: Opinion (Law) 977/65 & 1965 \\
\hline \multirow[t]{6}{*}{36} & Institute of Chemistry of São Paulo & 1970 \\
\hline & I PNPG & 1975-1979 \\
\hline & II PNPG & 1982-1985 \\
\hline & III PNPG & 1986-1989 \\
\hline & IV PNPG- Discussion of the Brazilian Post-Graduation & 1996 \\
\hline & V PNPG & 2005-2010 \\
\hline
\end{tabular}

Elaboration: Authors' work based on Córdova (1986) and Guterres (2001). 
In analyzing Table 1, we can talk of the development of science in Brazil for almost 150 years. However, there has been an intensification of the Stricto Sensu programs in the last 40 years due to reasons offered by authors like Silva and Carvalho (2007): either the intensification was motivated by the supply (stimulation of public support programs) or by the dynamics of demand (greater appreciation of the program and diploma, increase of a qualified and interested public, and greater public incentives such as scholarships).

Table 2 shows the evolution of the number of dissertations and theses produced by students in the Stricto Sensu programs since 1990 and identified in the SCIELO.br database (the largest bibliographic database of Latin American scientific productions).

Table 2. Dissertations and theses from the "Stricto Sensu" programs downloadable from Scielo- Scientific Electronic Library Online

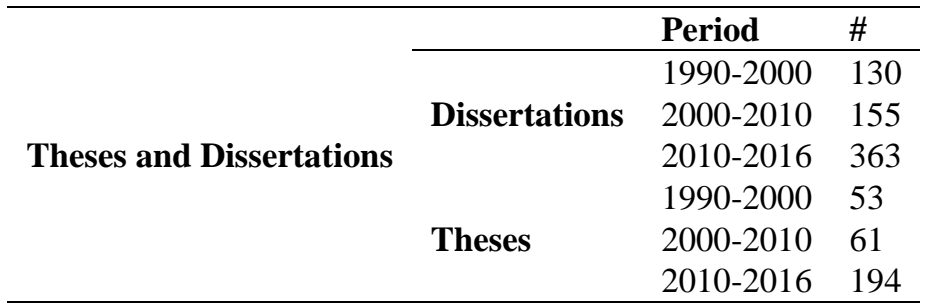

Elaboration: Authors' work based on Capes (2018).

In this period, the reflection produced in academic circles on the evolution and socio-economic reach of the Stricto Sensu programs was built on three main vectors: the question of the uniformity/heterogeneity of the curricula, the need for training and the role of trainees' autonomy in the process, and the balance of the program form in view of the graduates' vocation in response to external challenges. Let us discuss these vectors.

\subsection{The Issue of Standardization/Heterogeneity of Curricula}

We will begin this discussion with the question raised by Garcia (1999) about the concept of the initial formation of the academicians; he shows little confidence in the possibility of constructing a curriculum for the initial formation of the university professor. Garcia (1999) believes that it is more acceptable to speak of "initiation programs in the teaching profession". Referring to public policy questions, Morosini (2001) states that university teaching has been considered a box of secrets, marked by omissions regarding the teaching process. We do not deny that new references are appearing that address the understanding and organization of the methods of initial and continuing training of educators to prepare them for multifaceted performance. The current historical moment is characterized by the need for a renewal of educational know-how, both in terms of updating in relation to the specific knowledge of the disciplines for which the teacher is responsible, but also for an urgent reason, as regards the nature of pedagogical doing, that is, the domain of praxis, which is historical and unfinished (Barilli, 1998).

The organization of the central pillar of higher education, based on the triangle teaching-research-extension, describes academic formation as a response to three processes: a) transmission and appropriation of historically systematized knowledge (teaching), b) construction of knowledge (research), and c) objectification or materialization of this knowledge (extension). Thus, in higher education there will be communication between levels of teaching (undergraduate, specialization, master's, and doctorate), as well as articulation between research and teaching, in addition to the important mediation with society in general. Research, teaching, and extension still allow social integration as an "institutionalized practice" of learning. The organized society, it is hoped that education as an institutionalized practice will contribute to the integration of men into the threefold universe of practices that weave their concrete historical existence: in the universe of work, scope of material production and relations economics; in the universe of sociability, the sphere of political relations, and in the universe of symbolic culture, the sphere of personal consciousness, subjectivity and intentional relations (Severino, 2008)

Therefore, it is important and necessary to educate teachers who question, investigate, and are creative in finding ways to respond to the challenges of educational practice, particularly in the area of post-graduate studies. Regarding self-criticism, have a lack of understanding on the part of teachers and institutions about the need for specific preparation to practice teaching" (Isaia, 2006). According to the author, Even though they are aware of their formative function, teachers do not consider the need for such preparation and believe that the specific knowledge developed in the years of initial or on-the-job training, in addition to professional practice, is enough 
to ensure a good teaching performance (Isaia, 2006).

The need for training and the role of trainee autonomy in the process. However, if the specificity and identity of the teaching profession is teaching, it is unacceptable that university professors who hold the domain of knowledge in a scientific field do not receive proper formation as teachers. This question of teaching in higher education implies that there is a certain set of declined responsibilities whose omission is justified by the defense of autonomy. In this sense, it is up to the teacher in the academy to search for ways of improving their teaching practice (Pimenta \& Anastasiou, 2002). Institutions of higher education should understand the formation of the teacher as the place of autonomy. However, challenges must be met if teachers are to become increasingly devoted to improving their teaching and intellectual training. Otherwise, obtaining the knowledge to teach is up to each individual and his commitments and actions. Although the teachers have significant experiences and trajectories in their specific area of knowledge, it is common in the different institutions of higher education, the predominance of unpreparedness and even a lack of scientific knowledge of the teaching and learning process, by which they become responsible from the moment they enter the classroom (Pimenta and Anastasiou , 2002).

Higher education institutions must have as one of their most important roles the viability of this teaching practice, stimulating and providing conditions for teachers to prepare for the exercise of teaching (Veiga, 2006). According to Masetto (2003), training for teaching practice, more specifically teaching at university, does not have a history of significant investment. Thus, knowledge about teaching was for a long time analyzed as superfluous, used to serve as a prop to disciplinary knowledge. Therefore, the processes that involve learning and the knowledge related to the act of teaching have been placed in the background, left to the context of practice, in the hopes that those who master some specific knowledge can teach.

In relation to the criteria adopted in the Brazilian academic culture, a career of teaching in higher education requires masters' and/or doctorate degrees. Because of this, many educators now begin their careers as teachers at advanced levels of functional progression. However, the issue of prior preparation for teaching continues without necessary support. Teachers are faced with the lack of institutional actions to support them and the very lack of knowledge that teacher education is a complex process that requires the construction of systematically organized strategies that involve personal and institutional efforts (Isaia, 2006). For Masetto (2003), considering comments on professionalism reveals that didactic and/or pedagogical training constitutes the least valued area among academic professors.

The term "professionalization" presents different meanings according to the specific context of its use, defined by the dialectical relations of the objective and subjective characteristics that guide the processes of construction of professional identities. Professionalization is a way of representing the profession as a continuous process throughout the history of teaching and is an ideological movement insofar as it rests on new representations of the education and being of the teacher within the educational system. It is a process of socialization, communication, recognition, decision, and negotiation between individual projects and those of professional groups. But it is also a political and economic process, because at the level of practices and organizations it induces new ways of managing teaching work and power relations between groups within and without the school institution (Núñez \& Ramalho, 2008).

Many higher education teachers have never had the opportunity to be in touch with the classroom, or perhaps others see it as a superfluous practice and do not feel the need for exercising their teaching activity for reasons ranging from the devaluation of that dimension to individual vocations more focused on research. However, it is common among higher education teachers who have already worked as primary and secondary school teachers to recognize that the pedagogical experience was very important for their teacher training in higher education, which emphasizes that teaching experience is essential for training teachers. These experiences may arise from the fact that when they were students they had several teachers and were able to reflect on their teaching methods and choose what to use and what to discard. Also, they know about being educators and evaluating the experiences of others, colleagues for example (Santos \& Lima, 2008). Seeking a differentiated, critical, and transformative education of the subjects involved in the educational process, Nóvoa (1992) states that "the formation of teachers must provide autonomous thinking in a critical-reflective sense". This formation must support the personal development of the educator so as to build and maintain his/her sense of self-esteem.

\subsection{Emerging Challenges}

Thus, the work of teaching requires a careful look at the entire educational process. However, two important articles in the Law on Guidelines and Bases of Education (LDB 9394-96) do not address the need for specific knowledge for university teaching. Articles 65 and 66 state that the teaching practice should be 300 hours and that the preparation for the exercise of the master's degree will be done at the post-graduate level, mainly in 
master's and doctoral programs.

In this law (LDB 9394-96), there is no comment on the didactic-pedagogical training to be developed in the Stricto Sensu post-graduate courses, and the training model that has been developed relies on specialization rooted in a specific area of knowledge. In the Stricto Sensu courses, researchers have been trained, however, they are for the most part inadequately trained for the teaching life. This situation is paradoxical, since most of these researchers, when incorporated into universities, will act as teachers, not only as researchers. Even if they have devoted their lives to research, it will be these researchers who will teach or strive to teach. Melo Teixeira (2009) reinforces this idea by stating. In a certain way, in the case of teacher training to act in basic education there is a concern with the development of different pedagogical knowledges and practices, among them teaching practices, methodologies and the supervised stage. On the other hand, for teaching in technical courses and in higher education the focus is on scientific competence, devoid of the didactic-pedagogical dimension (Melo Teixeira, 2009).

Thus, in Brazilian higher education institutions, there is a relative devaluation of teaching compared to the development of academic research demonstrated by the number of research productions, which is currently the most relevant criterion for evaluating productivity and teaching quality. Pimenta and Anastasiou (2002) conclude that no matter how productive a researcher is in creating academic work of significance addressing theoretical questions, this does not guarantee that the professor-researcher will provide a satisfactory didactic-pedagogical performance. It is important to emphasize the evaluation of research as something fundamental to teaching practice, in agreement with Erickson (1986), who affirms that to research is, especially, to reflect critically on the teaching practice. Who is most interested in this reflection if not the teacher? Any conscious professional should constantly reflect on their practice.

Based on the relevance of reflection on teaching in research practice, it is believed that educators need to reformulate their thoughts about their teaching roles and develop their pedagogical ability with structured and dynamic methods as ways to stimulate learning and to develop the self-confidence of their learners. It is imperative that universities seek to make teachers work towards contributing to the effective transformation of the university into a locus of innovative knowledge production through the inseparable practices of teaching, research and extension, as a foundation of the teacher training itself, an aspect that unfortunately still seems to be far from materializing in the scenario of teacher training in the university environment. (Severino, 2008).

According to Libâneo (2009), the educator needs to have, above all, curricular training in the discipline that he/she teaches, as well as didactic-pedagogical training, so that there is a link between the "general principles governing the relations between teaching and learning, with specific problems of the teaching of a given subject". Knowledge and practices such as those described are important, because teaching is a complex activity, full of contexts, often unpredictable, due to the influence of ethical, political, cultural, and social issues (Pimenta \& Anastasiou, 2002). In this sense, teacher knowledge is based on experience and theoretical research emerging from reflection and institutional actions. Therefore, the formation of the educator requires academic investments so that teachers can establish a relationship with theory and practice, as well as a context of production of historical-social knowledge. This formative action encourages teachers to understand and develop their educational practice. In this context states that even if the teacher and student are, there is no teaching without discussion; the two are explicated and their subjects, despite the differences they have, are not reduced to the condition of being an object of the other: those who teach learn while teaching and those who learn teach when learning (Freire, 1996).

However, the academician does not often have significant scientific knowledge of the elements that make up the teaching practice itself, which are related to planning, class organization, teaching methodologies, didactic strategies, and evaluation and details of the teacher-student relationship; because there was no specific training for the teaching/learning process. The general table of the formative processes of university teachers in the Stricto Sensu graduate programs is characterized by the preparation through the development of theoretical and instrumental knowledge of the activity of research and production of knowledge, with appropriate references to the field (Almeida \& Pimenta, 2009). The Stricto Sensu graduate programs are thus identified as important as far as research is concerned. However, as emphasized by several authors, a new recognition of the relevance of the didactic-pedagogical training of the teacher is necessary.

The attention of the academics themselves in the reflexive process of the Stricto Sensu programs is present in the list of productions emerging from these programs. Table 3 presents a listing obtained from the most intensive bibliographic database of material published in Portuguese as well as from higher education institutions in Brazil, SciELO.br (Cintra, 2018). We conducted an exhaustive research of titles and abstracts as well as keywords of 
publications, and we chose those publications that had the term "stricto sensu" in some of these fields. We also point out the period coinciding with the period where there are bibliographic entries recognized on the subject by Scielo.

Table 3 reveals the trend in the number of reflective publications on Stricto Sensu programs, with a focus on health and human sciences.

Table 3. Publications focused on "stricto sensu" in SciELO - Scientific Electronic Library Online

\begin{tabular}{clccc}
\hline Database & Period & Scientific field & Stricto Sensu \\
\hline \multirow{2}{*}{ Scielo } & \multirow{2}{*}{$2007-2017$} & Health Sciences & 11 \\
& & Social Sciences & 10 \\
\multirow{2}{*}{ Books } & Period & Books'chapters & Full books \\
& & $2000-2012$ & 2 & 0 \\
\hline
\end{tabular}

Elaboration: Work of the authors (2018) on SciELO (2018).

\subsection{Empirical Section - a Content Analysis of the Consulted Publications}

In order to deepen the richness of the material collected in the identified bibliography, we decided to follow authors such as Robert and Bouillaguet (1997) and Gil (2017) and perform a detailed content analysis of the titles and abstracts in publications identified in the Web of Science DataBases, Scopus, and ResearchGate. Searching for the term "Stricto Sensu" we identified 48 articles, 24 theses/dissertations, and 27 working papers. The median impact factor of the journals publishing the 48 papers was 0.87 ; the impact factor of these journals has been increasing since 2010. The detailed content analysis is structured in three steps: analysis of the frequency of relevant terms, analysis of the association of relevant terms, and the differential structuring of discourses. As a software resource, we used the Iramuteq software v 0.7 alpha 2 . This set of steps was suggested by Chaumier (1997) and Heider (1970) and has been reported in a number of relevant works in the social sciences literature (we refer to an increasing number if observed from year to year). It aims to complement the bibliometric analysis that is limited to choosing - sometimes with excessive arbitrariness (Guessard, 2000) indicators and positioning them in categories related to the hypotheses.

We recall that the first step is the analysis of the frequency of the relevant terms. A relevant term is a term or set of associated terms that appears with a significant frequency in the studied messages or with a key position in the messages' network (Robert \& Bouillaguet, 1997). Several papers have addressed the importance of studying the frequency of terms. Works in the field of psychology associate the frequency of certain words or expressions with varied motivations located in the issuer or in the intentions of the issuer (Mertens, 1992). Generally, the issuer who often expresses a certain term intends to focus his attention on a problem (Jung, 1910), to emphasize the need for recipients to cooperate in solving the problem (Mezan, 2002), or to trigger associated action . Other works, from textual analysis in literature (Define, 1975) to political science (Domenach, 1973), point out that the most frequent relevant terms of a given content are intended to exert a rhythmic pace, to reinforce the focus on the perceived action as being more urgent. In the field of social sciences - in particular the bibliometric sciences - there is an increasing number of works that have gone through this stage. They do this essentially to investigate how certain agents/authors prioritize the observation of certain hypotheses tested by qualitative methods or how they manifest needs for social action considered more urgent.

In addition to Table 3, which shows the distribution of frequencies of the set of respondents, we will refer to Figure 1 - a simple visualization (a "cloud of words") - which relates the size of each word with the associated frequency. 
Table 4. Frequency of the terms in the studied titles and in abstracts

\begin{tabular}{ll}
\hline Terms & Frequency \\
\hline postgraduate & 75 \\
sensu & 67 \\
university & 65 \\
stricto & 63 \\
program & 63 \\
article & 47 \\
research & 46 \\
health & 40 \\
federal & 36 \\
train & 33 \\
pedagogical & 33 \\
science & 32 \\
education & 32 \\
www & 30 \\
researchgate & 30 \\
net & 30 \\
https & 30 \\
publication & 29 \\
student & 27 \\
nurse & 27 \\
teach & 26 \\
study & 26 \\
result & 25 \\
\hline
\end{tabular}

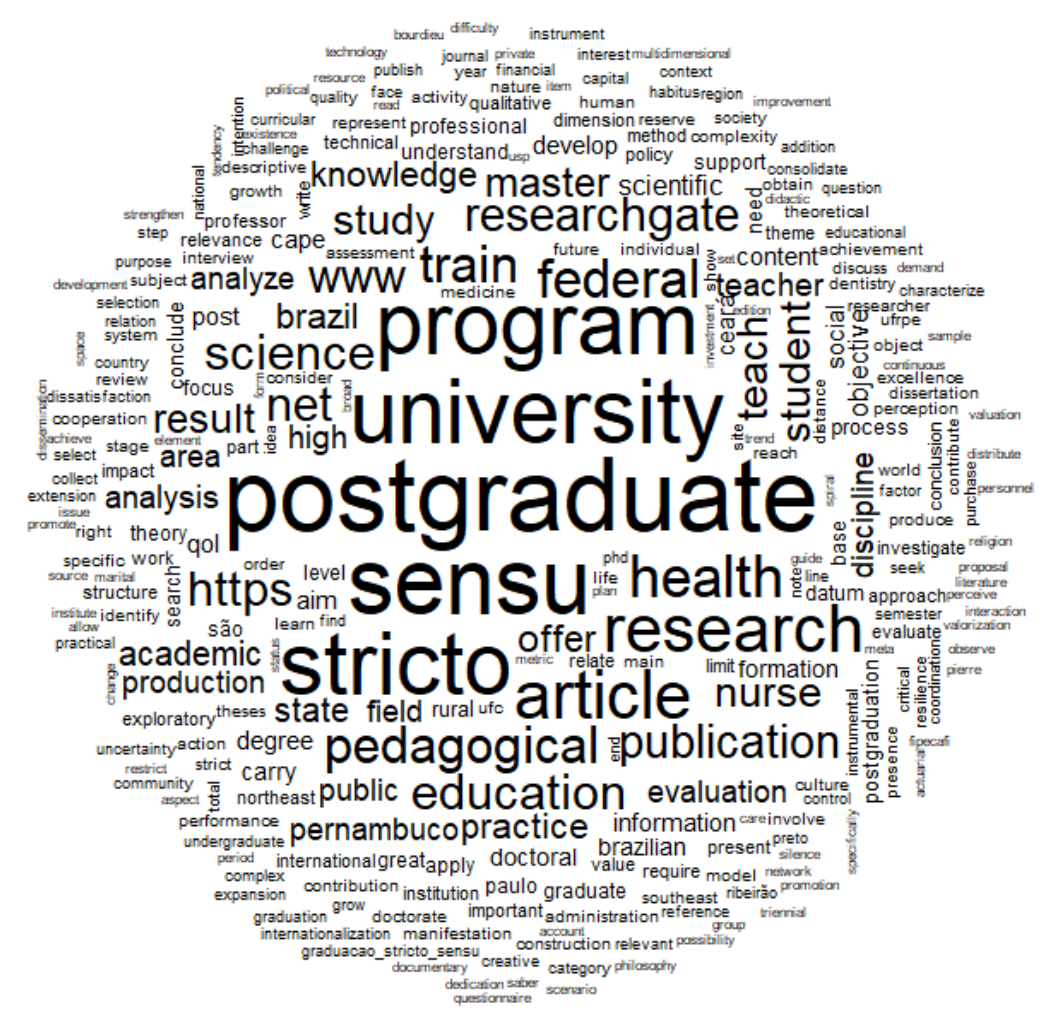

Figure 1. Word cloud of the studied titles and abstracts

As can be seen, the most frequent terms are post-graduate, sensu, university, stricto, program, article, and research. From the previous observation, we verified that the hypothesis for the focus of the Brazilian Stricto 
Sensu programs on research (to the detriment of pedagogy) is validated once again.

In order to avoid multiplying the analysis of the most relevant terms according to variables or modalities to be considered (e.g., whether or not the article/publication was signed by Brazilian authors, etc.), other methodological procedures were developed, namely, the association of words or of expressions by Factor Analysis and by "similitude." The corresponding Factor Analysis of the terms allows us to group the terms identified as relevant. The terms are distributed according to the score loadings assigned by a Factor Analysis process. Works that focus on the details of Factor Analysis applied to the world of content analysis are Reinert (1983) and Reinert (1990). Therefore, in order to opt for parsimony in approach as well as to speed up the pace of this work, we will omit these details. Simply, Factor Analysis condenses the diversity observed in the texts into factors that represent latent dimensions. This process allows the distribution of the terms (but also the publications) by the main factors - eminently, two factors - which allows the verification of which terms are neighbors to each other (belonging to common dimensions) and which subgroups use a closer content structure between them.

The results of the Factor Analysis on the set of analyzed texts led to the construction of Figure 2 and Figure 3.

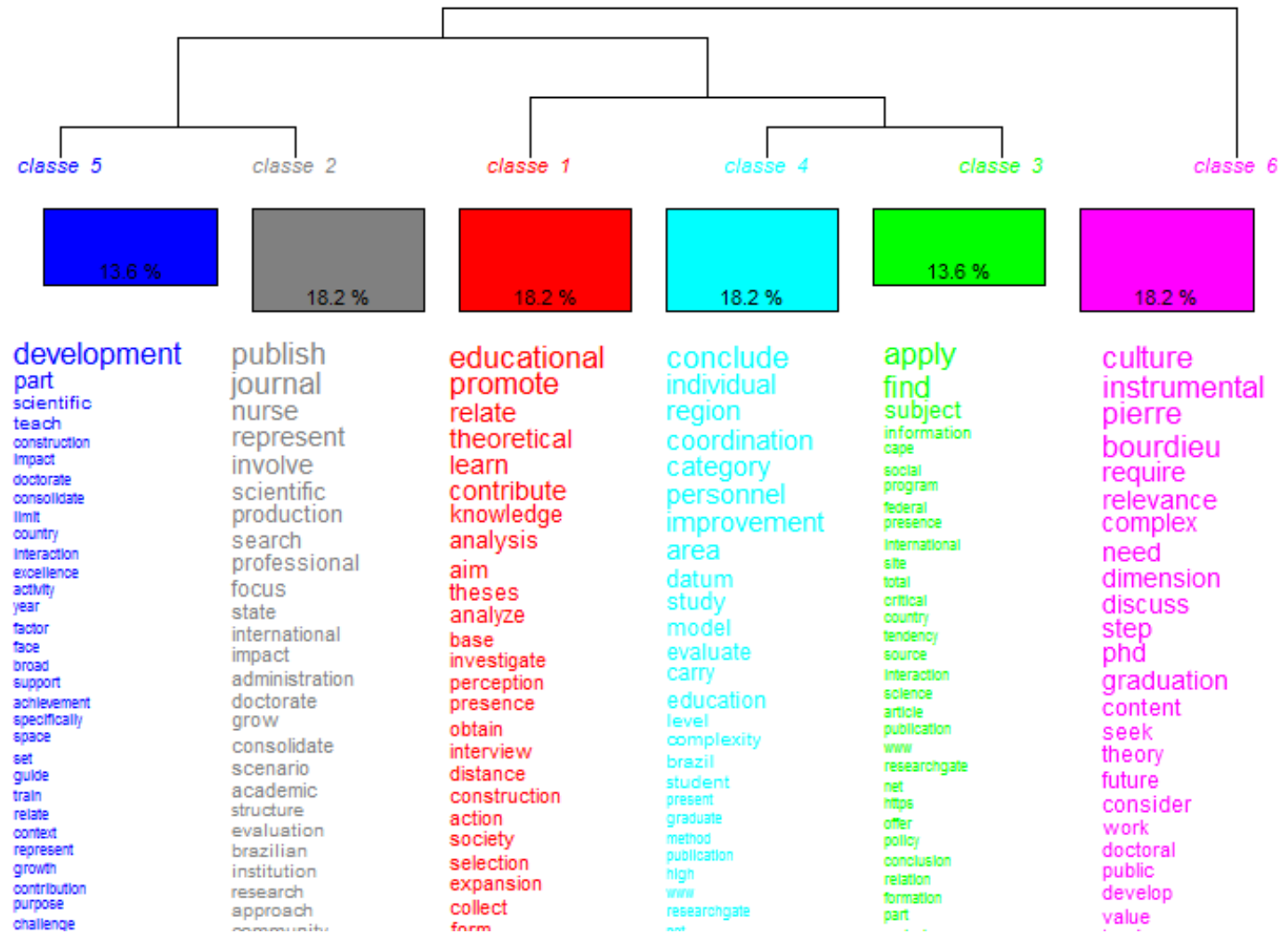

Figure 2. Factor Analysis of the scientific publications focused on the Stricto Sensu programs in Brazil 


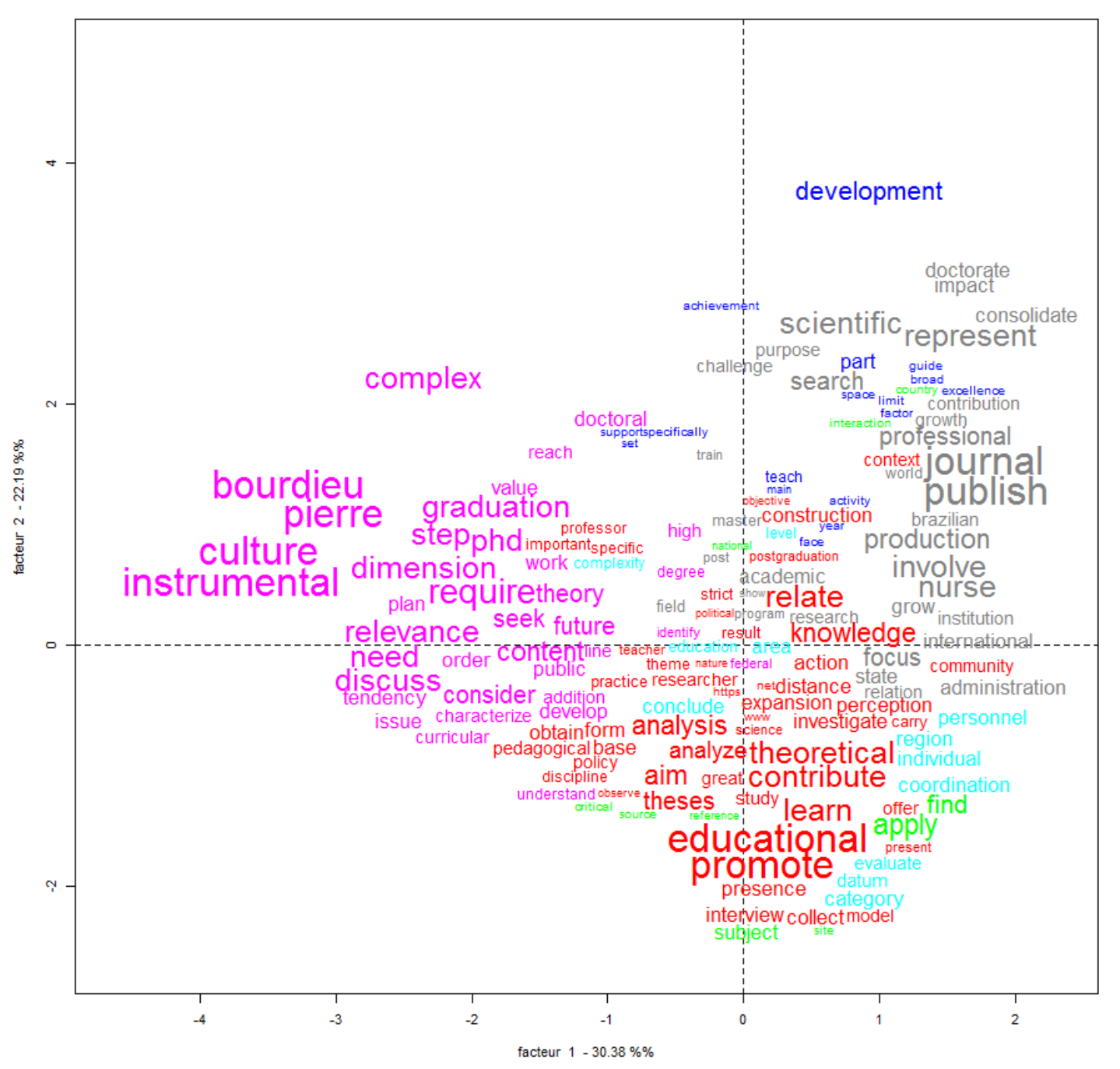

Figure 3. Distribution of content by factors

It was verified that there are four preponderant groups in the related works. The first is a core group using terms such as "knowledge-promote-educational" that are identified in red. This group includes authors like Masetto (2013) who show how the graduate programs also focus on the issue of knowledge production based on collaboration with the educational axis. There are then more "peripheral" groups that show the concentration of items observed in particular groups of publications. For example, the purple set consists mainly of publications that have published studies on the cultural/sociological impact of the programs in the local and regional context. The sets of blue and gray terms are close to each other (Fig. 3 and 4) and relate to the publications most closely related to the use of Stricto Sensu's programs as inductive sources of scientific production.

The analysis by similitude allows, in turn, a deepening of the association of terms of relief in the analyzed responses (Moliner \& Vidal, 2003). It differs from the Factor Analysis because the analysis by similitude, using a methodology from network theory, associates "central" words with the remaining terms based on "centrality" value. Unlike the Factor Analysis associated with Figures 2 and 3, similitude analysis is more focused on the direct link between the terms, showing those that are central (i.e., frequent terms in the flow of messages but also revealing the terms which act as "bridges" with the remaining terms). As Figure 4 shows, the analyzed publications associate "post-graduate" (one of the central terms) with other terms like "program," "education," and "research." There is very interestingly a circuit between the central terms "post-graduate," "research," "university," and "Stricto Sensu." Thus, we find that the terms "program" and "education" are more peripheral in the mesh of terms (converging with our central hypothesis). 


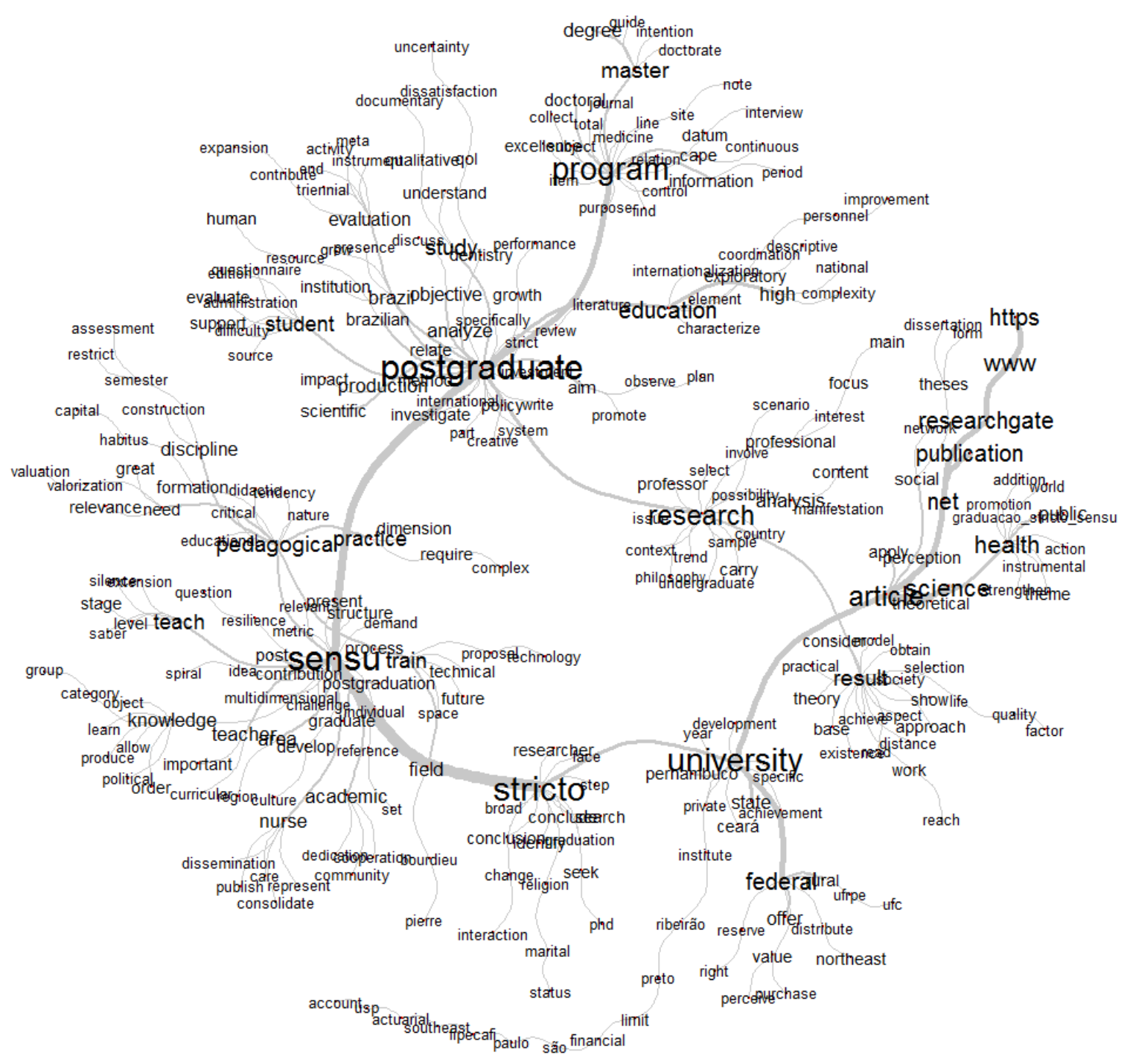

Figure 4. Similitude analysis of the content of scientific publications focused on Stricto Sensu programs

\section{Results}

Our results strengthen the warning from several scholars such as Garcia (1999) and Barilli (1998): Brazilian post-graduate programs have been essentially focused on providing students a research profile. The interpretation of our results show that most of the publications centered around Stricto Sensu highlight the importance of the research dimension. Authors like Coelho (1996) claim that the pressure coming from comparative metrics across different professors, departments, and universities worldwide has caused post-graduate programs to focus on the development of research tools for most academicians. Additionally, the ideas of "best researcher" and "best professor" have gained a foothold in academic debates (Isaia, 2006). Along this line, Figure 4 shows how the term "professor" appears close to "research." Finally, despite the relevance attributed to the research work of academies, our content analysis still identified the significance of terms related to the didactical/pedagogical role of post-graduate programs. However, the mostly neglected third leg of the "academic triple," - i.e., the civic extension of the programs - has hardly been identified as significant given the sample of publications we read. Actually, in Figure 4 we can observe how terms like "community" or "dissemination" appear at peripheral locations, essentially linked to the term "Stricto Sensu."

\section{Discussion -Conclusion and Recommendations}

This work made an exhaustive survey of publications focused on Stricto Sensu post-graduate courses in Brazil. Through a content analysis of the identified literature, it was possible to confirm the recognition of these 
programs as research oriented, threatening to make secondary the pedagogical dynamics and social extension that have been included from the beginning in the Stricto Sensu courses. From these results, we suggest the following implications.

Encouraging didactic-pedagogical training is important in Stricto Sensu post-graduate programs as well as in Brazilian public policies for higher education. It is necessary to construct, in a collective way, measures aimed at valuing the teaching practice in the academy, so that the act of teaching is not seen as a burden, either for the State or for individuals, but as part of the essence of the university.

We begin from the premise that academic formation is a complex action that requires an effective strategy in its preparation as well as in creating adequate working conditions to provide learning opportunities for teachers to meet the unique needs of the profession. Post-graduate courses, primarily Stricto Sensu, are responsible for the training of academicians; however, there has been an overemphasis on research alone and very little or nothing in relation to teacher training for master's and doctoral students.

The richness of the approach presented in this work allows two emerging developments. The first relates to the possibility of extending the relationship between the publications and the authors identified in this work through an analysis of the networks of publications that will be possible using software such as VOSviewer. The second development aims, through comparable methodological resources, to extend this analysis to other Latin American post-graduate realities in order to clarify in a generalized way the tendencies that these training programs are developing.

\section{References}

Almeida, M. I., \& Pimenta, S. G. (2011). Pedagogia universitária: valorizando o ensino e a docência na Universidade de São Paulo. In: Pimenta, S. G.; Almeida, M. I. (orgs.). Pedagogia universitária: caminhos para a formação de professores. São Paulo: Cortez.

Anastasiou, L. (2002). Construindo a docência no ensino superior: relação entre saberes pedagógicos e saberes científicos. In: Rosa, D.E. G. \& Souza, V.C. (orgs.) Didáticas e práticas de ensino: interfaces com diferentes saberes e lugares formativos. Rio de Janeiro, Editora DP\&A.

Barilli, E. (1998). Formação continuada de professores - Por quê? Como? E pra quê? Tecnologia Educacional, Rio de Janeiro: Associação Brasileira de Tecnologia Educacional.

Borgatti, S. P., Everett, M. G., \& Freeman, L. C. (2002). Ucinet 6 for Windows: Software for Social Network Analysis. Harvard, MA: Analytic Technologies.

Chaumier, J. (1997). L'Analyse documentaire ou la valorisation des documents. Paris: Recherche en soins infirmiers.

Cintra, P. (2018). The scientific production on teaching in higher education: a bibliometrics analysis of SciELO Brazil. Scielo, 23, 567-585. http://dx.doi.org/10.1590/s1414-40772018000200016

Coelho, I. M. (1996). Formação do educador. São Paulo: UNESP.

Constitutição do Brasil. Parecer nº 977/1965. Definição dos Cursos de Pós-Graduação no Brasil, Brasília, Brasil.

Coordenação de Aperfeiçoamento de Pessoal de Nível Superior. (2017). Relatório da Avaliação Quadrienal 2017. Retrieved from http://www.capes.gov.br/images/documentos/Relatorios_quadrienal_2017/20122017-Geografia_relatorio-de -avaliacao-quadrienal-2017_final.pdf

Córdova, R, A., Gusso, D., \& Luna, V. (1986). A Pós-graduação na América Latina: o caso brasileiro. Brasília: UNESCO/CRESALC/MEC/SESu/CAPES.

Defina, G. (1975). Teoria e Prática de Análise Literária. São Paulo: Livraria Pioneira Editora.

Domenach, J. (1973). A propaganda política. Lisboa: Círculo Leitores.

Erickson, F. (1986). Qualitative methods in research on learching. In: Wittrock, M. C., ed. Handbook of research on teaching (3nd ed.). New York: Macmillan Publishing.

Freire, P. (1996). Pedagogia da autonomia: saberes necessários à prática educativa (34.ed.). São Paulo: Paz e Terra.

Garcia, C. M. (1999). Formação de professores: para uma mudança educativa. Portugal: Porto Editora.

Gil, A. (2017). Como elaborar Projetos de Pesquisa. São Paulo: Atlas Editora. 
Guessard, Bruno. (2000). Ethique du documentaliste, éthique de l'usage de la documentation. Retrieved from http://www.rndh.fr/documents/actualites/pdf/2000_33.pdf

Guterres, C. (2001). A Faculdade Interamericana de Educação. Projeto Multinacional de Aperfeiçoamento de Pessoal Especializado em Educação, 1970-1977 (Tese de doutorado). Universidade Federal de Santa Maria, Rio Grande do Sul, Brasil.

Heider, F. (1970). Psicologia das Relações Interpessoais. São Paulo: Biblioteca Pioneira de Ciências Sociais.

Instituto Brasileiro de Geografia e Estatística. (1939). Histórico da criação do Conselho Nacional de Geografia. Revista Brasileira de Geografia. 1939. Retrieved from https://biblioteca.ibge.gov.br/visualizacao/periodicos/115/rbg_1939_v1_n1.pdf.

Isaia, S. (2006). Desafios à docência superior: pressupostos a considerar. In: Ristoff, D. \& Sevegnani, P. Docência na Educação Superior. Brasília: INEP.

Jung, C. G. (1910). The association method. The American Journal of Psychology, 21(2), 219-269. http://dx.doi.org/10.2307/1413002

Libâneo, J. C. (2009). Conteúdos, formação de competências cognitivas e ensino com pesquisa. In: Pimenta, S. G.; Almeida, M. I. de (orgs.). Pedagogia universitária: caminhos para a formação de professores. São Paulo: Cortez.

Masetto, M. T. (2003). Competência pedagógica dos professores universitários. São Paulo: Summus.

Masetto, M. T. (2009). Professor universitário: um profissional da educação na atividade docente. In: Masetto, M. T. (Org.). Docência universitária. 10.ed. Campinas: Papirus.

Melo Teixeira, G. F. (2009). Docência: uma construção a partir de múltiplos condicionantes. Boletim Técnico de SENAC, Rio de Janeiro, 35(1), 29-37.

Mertens, T. (1992). O Teste de Associação de Palavras na Psicologia e Psiquiatria: História, Método e Resultados. Revista Análise Psicológica, 15(1), 31-541.

Mezan, R. (2002). Sobre a epistemologia da psicanálise. In: R. Mezan. Interfaces da psicanálise. São Paulo: Companhia das Letras.

Ministério da Educação do Brasil. (1996). Lei de Diretrizes e Bases da Educação Nacional Nº 9.394/96. Brasília, Brasil.

Moliner, P., \& Vidal, J. (2003). Stéréotype de la catégorisation et noyau de la représentation. Revue Internationale de Psychologie Sociale, 16(1), 157-176.

Monteiro, C. A. F. (1980). A Geografia no Brasil (1934-1977): avaliação e tendências. São Paulo: IGEO-USP.Moreira, R. (2010). Geografia e Práxis: a presença do espaço na teoria e na prática geográficas. São Paulo: Contexto.

Morosini, M. C. (2001). Docência universitária e os desafios da realidade nacional. In: Professor do ensino superior: identidade, docência e formação (2nd.ed.). Brasília: Plano Editora.

Nóvoa, A. (1992). Vidas de professores. Porto: Porto.

Núñez, B. I., \& Ramalho, L. B. (2008). A profissionalização da docência: um olhar a partir da representação de professoras do ensino fundamental. Revista Iberoamericana de Educación, 9(46), https://doi.org/10.35362/rie4691872.

Pimenta, S. G., \& Anastasiou, L. (2002). Docência no ensino superior. São Paulo: Cortez.

Porto, C., \& Régnier, K. (2018). O Ensino Superior no Mundo e no Brasil - Condicionantes, Tendências e Cenários para o Horizonte 2003-2025- Uma Abordagem Exploratória. Retrieved from http://portal.mec.gov.br/sesu/arquivos/pdf/ensinosuperiormundobrasiltendenciascenarios2003-2025.pdf?fbc lid=IwAR0dH1YCQ413s-SPnUMSgkdFErFLvXodlGLcMuyRfmEzPeTVAvXa7m4kyQ0

Reinert, M. (1983). Une méthode de classification descendante hiérarchique : application à l'analyse lexicale par contexte. Les cahiers de l'analyse des données. Retrieved from http://www.numdam.org/item?id=CAD_1983_8_2_187_0

Reinert, M. (1990). Alceste une méthodologie d'analyse des données textuelles et une application: Aurelia De Gerard De Nerval. Bulletin of Sociological Methodology/Bulletin de Méthodologie Sociologique, 26(1), 24-54. https://doi.org/10.1177/075910639002600103 
Robert, A., \& Bouillaguet, A. (1997). "L'analyse de contenu (Broché)”. Paris: PUF Editeur.

Rolnik, R. (1994). São Paulo, início da industrialização: o espaço e a política. In: Kowarick, L. As lutas sociais e a cidade: São Paulo, passado e presente. Rio de Janeiro: Paz e terra.

Santos, M., \& Silveira, M. L. (2001) O Brasil: território e sociedade no início do século XXI. Rio de Janeiro: Record.

Santos, W., \& Lima, M. (2008). Ser professor no ensino superior: a contribuição dos grupos de estudos na formação pedagógica do docente universitário. In: Salão de Extensão e Cultura 2008: estabelecendo diálogos, construindo perspectivas. Guarapuava: Unicentro, Paraná, Brasil.

SCIELO. Scientific Eletronic Library Online. Retrieved from https://search.scielo.org/?q=Stricto\%20sensu\&where=SCL.

Sevegnani, P., \& Ristoff, D. (2005). Docência na educação superior. Brasília: Instituto Nacional de Estudos e Pesquisas Anísio Teixeira, Ministério da Educação do Brasil.

Severino, A. J. (2008). Ensino e pesquisa na docência universitária: caminhos para investigação. Caderno de Pedagogia Universitária. São Paulo: FEUSP.

Silva, M., Carvalho, D., \& Bomtempo, B. (2007). A Pós-graduação e a produção de conhecimento no serviço social brasileiro. Revista Brasileira de Pós-Graduação, Brasília, 4(8), 192-216.

Veiga, I. P. A. (2006). Docência universitária na educação superior. In: Ristoff, D; Sevegnani, P. (orgs.). Docência na Educação Superior. Brasília: Instituto Nacional de Estudos e Pesquisas Anísio Teixeira, 2006

\section{Copyrights}

Copyright for this article is retained by the author(s), with first publication rights granted to the journal.

This is an open-access article distributed under the terms and conditions of the Creative Commons Attribution license (http://creativecommons.org/licenses/by/4.0/). 